\title{
Exiting Europe, Exciting Postcoloniality ${ }^{1}$
}

\author{
QADRI ISMAIL \\ Professor of English, University of Minnesota
}

The trouble with dead white men is that some are not men, many not white, and an alarming number not even dead. Put differently, since individuals, dead or alive, are not at stake: eurocentrism suffuses, saturates, structures the modern episteme. It is here: apartheid, in Hendrik Verwoerd's formulation, ${ }^{2}$ separates European from nonEuropean races; there: the English department I teach in has just one 'single author' requirement, Shakespeare; and everywhere: the prime meridian, a geopolitical not geographic delineation, traverses London, frames time globally; we reinforce eurocentrism every time we do something as banal, quotidian as check the time.

Our politico-epistemological moment may understand itself, here and there, though not everywhere, as postcolonial; the continuing force of eurocentrism, its ubiquitous reach, ineluctable cunning, its cemented sediment solicits a (re)conceptualisation of postcoloniality. Dominantly, inadequately taken at our moment as addressing developments during and/or after colonialism in a place once named the third world, eurocentrism incites the recharging of postcoloniality in non-historicist, non-geographic - in South Africa at this intersection, one may even have to say nonor anti-decolonial - terms. A rethinking of both prefix and noun: in what sense is postcoloniality post or after something, its object, target? Is that thing it comes, goes after, that target properly nominated as colonialism? Theoretical, anti-disciplinary in its initial articulation - Partha Chatterjee's Nationalist Thought an exemplary text ${ }^{3}-$ postcoloniality attenuates its charge with the reassertion of culturalism, historicism, identity politics, as the subsequent writing of Chatterjee attests. (Charge, OED: brief, burden, responsibility, mandate, excitement, energy, value.) This essay recharges postcoloniality as the undertaking to finish the critique of eurocentrism.

As much as it unsettles me to say this, Hegel said it first. And didn't, for first gets established belatedly, retrospectively, after second. In a Nietzschean, even Freudian, sense second comes first. Someone called Elizabeth I ruled England - and Ireland only after Elizabeth II.

Hegel had it first, the last word, the first sentence of eurocentrism: 'Europe presents...the center and end of the old world, and is absolutely the West - so Asia is

\footnotetext{
This paper draws freely from my book Culture and Eurocentrism (London: Rowman \& Littlefield International, 2015).

Hendrik F. Verwoed, Verwoerd Speaks: Speeches, 1948-1966 (Johannesburg: APB Publications, 1966).

Partha Chatterjee, Nationalist Thought and the Colonial World: A Derivative Discourse? (Minneapolis, MN: University of Minnesota Press, 1993).
} 
absolutely the East.' ${ }^{3}$ The declaration holds Europe west and centre, centre and end, first and last; last, thereby first.

Hegel's Europe: on the one hand: centre, pivot, nucleus, foundation, heading, grounding/commanding principle; and the other: end, mature, conclusion, ultimate, telos. Europe as lasting, settled.

In différance, Asia: Europe takes its bearing, institutes the subject by pushing aside the other continent, the only other that matters, that matters only as other. The subject is never, is always already otherwise. Without Asia, Europe cannot make sense. But Hegel denies his precedent precedence.

Without Asia, no Europe. They are concatenated, inextricable. Hegel stages the continents as discrete; The Philosophy of History suggests they impress each other. Indeed, without Europe no Asia, for the latter gets named after a Greek goddess, stamped by Europe. Our goods maybe made in Asia; Asia itself, made in Europe. As, of course, is Africa, heterogeneously.

First and last, too, Asia; but first therefore last, supervened, superseded by the movement of history. A metacanonical figure, requiring - like Shakespeare - just one name, the last, for recognition, Hegel concedes that the sun also rises over that prior continent, but the merely 'physical Sun'. The mature 'Sun of self-consciousness, which diffuses a nobler brilliance, ${ }^{5}$ peeks exclusively at, peaks exclusively over Europe.

Another son, a transcendental figure - like Madonna - requiring only first name for recognition, promised, or so states the King James Bible, that the first shall be last and the last first, in heaven. Hegel effectively declared it so on earth. Of Europe.

One cannot engage Europe without confronting this authoritative emplotment of history, this determination of a place as place as such, this place that authors, names other places, others place. Though passé, it lingers, way past its expiry date, demands response. Eurocentrism incites, excites - calls, summons, sets in motion - its critique, postcoloniality. Coming both before and after, getting before in order to go after, postcoloniality, in turn, dares: without eurocentrism would there, could there be Europe? For Europe is not some indisputable geographic fact; the discipline concedes that Europe and Asia defy its definition of continent. Poses the question of disciplinary reason: does eurocentrism, a structure that systematically inflects - capes, if you like - another structure, the modern episteme, does the imperative to produce Europe as head/ing compel the concept continent, if not the discipline itself?

Continent divulges the relation between ideology and disciplinary reason, episteme. The georacial line incising, excising Europe from Asia also apartheids hierarchises, separates, but imperfectly - the white from the brown and yellow races, superintends contamination, the corruption of the one by the touch of the many.

Let me repeat the question that unsettles me, that I hope unsettles you, too: without eurocentrism, would there, could there be Europe? If Europe is homonym for eurocentrism, should there be Europe, this tautology, incontinent continent that never fit its descriptor. Brutally put: Europe has always been incontinent,

G.W.F. Hegel, The Philosophy of History, translated by J. Sibree (New York: Dover, 1956), 99.

Ibid., 19. 
unrestrained; open, in the name of the good, to conquering, settling, exploiting, infecting, inflecting, advising, patronising, degrading, carpet-bombing, terrorising a proper accounting would fatigue dictionary and diction - every other continent. Europe designed human rights, refined human wrongs. Its goods are bads. As response, could postcoloniality cathect Europe? (As Dipesh Chakrabarty, who finds it indispensable, its goods - like human rights - indisputably good, holds we should. Provincialising implies the downgrading of Europe from the global dominant to a mere region. It dare not pose the question of Europe. A Caucasian magnet, as you call the life sciences building, Chakrabarty attracts scholars like Wendy Brown precisely because he cannot pose the question of Europe.) Could postcoloniality, to take a term from John Mowitt, ${ }^{6}$ finish, exfiltrate Europe, conceive an after eurocentrism?

In The Wretched of the Earth, Fanon famously calls upon the third world to 'leave Europe', escape 'nauseating mimicry.' He charges Europe, conceived in graphic, not geographic terms, with unrestrained decimation - physical, psychic, epistemic - of that world.

Nevertheless Fanon, writing in French, cannot avoid repeating Europe, (re)citing the Bible, capturing decolonisation in a word, or three, as reversal, replacement, recentring; in a sentence, as making the last first and first last. The text divulges that the first lasts: 'The argument the native uses has been furnished by the settler.' Redoubling, shuttling between undoing and redoing, supercession and supervention, decolonisation emerges in Fanon's delineation as imitating the coloniser, finishing its project with settler furnishings.

Enraged, outraged by Europe, the text breaches the roadblocks imposed upon the colonised, who inhabit 'a world cut in two': 'a strongly built... brightly lit [settler] town... [against] a crouching village...a [native] world without spaciousness.' An apartheid sans formal structures, strictures. A first world in the third characterised by technology, expanse, a second that is also third, by restriction in general. The settler's sole commandment: thou shalt not.

Incarcerated at home, the native has no choice but to dream, dreams - upending Freud - as a matter of choice. He dreams of unrestricted movement, athleticism, exercising masculine muscle. Decolonisation cathects repose, to settle, secure the restless native, rework other as subject. Out of place in his place, the native aspires to forced removal, regurgitate the settler, a 'superfluous term'. To put the occupier in his place, 'out of the picture'. But fails.

Bound by day, boundless at night, in his dreams the native - by definition without - moves within, charges across the European zone, dazzling even after sunset. Transgressing the private, he wants to have, hold, harm, imagines 'all manner of

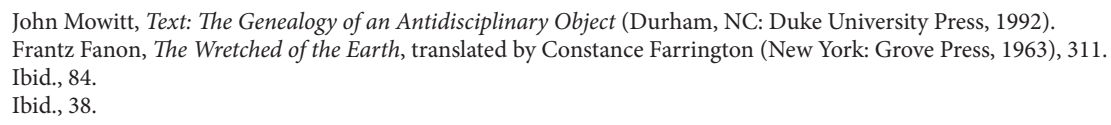


possession: to sit at the settler's table, to sleep in the settler's bed, with his wife if possible. ${ }^{10}$ Installs himself in the other's place, imaginatively but - upending Shelley - without empathy. Or, perhaps, empathises to steal, not feel. Empathy in any case, as Ross Truscott points out, ${ }^{11}$ following a predatory imperative. But the usurper remains in the picture, within the frame, if only as passé partout. To the settler's purloining, the native responds with loining; reacts to violence with violation, including violence towards women, an object analogous to other inanimate objects, furniture, accessories like bed and table. Divulging the heteropatriarchal frame that takes rape as vengeance, a violation of the man, not woman, Fanon's native taunts the settler: I will fuck you - and your wife.

The Wretched of the Earth stages the limits of native agency, of replacement as politics, decolonisation as programme, the difficulty of leaving Europe, thinking outside the modern episteme. Postcoloniality discharges decolonisation. Where decolonisation - and eurocentrism - settles, postcoloniality unsettles. To finish is not to postmortem, have the last word; rather, to recharge, re-energise the concept.

So, the text unsettles: 'The cause is the consequence; you are rich because you are white... white because you are rich. ${ }^{12}$ More Nietzsche than Hegel, the formulation conceptualises settler success as the effect of dominance, white privilege, not inherent racial capacity. Upends E.B. Tylor's claim that, as pigmentation lightens, civilisation brightens; history in Tylor's emplotment progressing as the colour line etiolates, from the brown races, through the yellow, to the white, 'latest' but first in the race of civilisation. (Iterating Hegel, Tylor situates the black outside history, as savage, an also ran.) Counterintuitively, incitingly, Fanon accounts for race, whiteness, as such an effect, not an anthropological or natural, scientific fact, binds concept and force. Race emerges in Fanon as colonialism's epistemic accomplice, indispensable to the work of interpellation - which takes, as Althusser's ${ }^{13}$ celebrated example reminds us, unawares, behind one's back - the production of separate and unequal: white as right; black, lack. For the converse also holds: black as the category, cell of white, of eurocentrism, not signifier of inherent ipseity. Without white, as Tylor also demonstrates, differently, there would, could never have been black. Fanon's argument shakes the ground of identity politics before it could take. Like Europe and Asia, native is always already fissured by settler; black, extimate to - inside and outside white, not identical to itself.

Composed as it is, the text decomposes, divulges its failure (and poses the question, measure of success): 'every time Western values are mentioned they produce in the native a...stiffening or muscular lockjaw... when the native hears a speech about

10 Ibid., 39.

11 Ross Trusscott, 'Empathy's Echo: Post-Apartheid Fellow Feeling', Safundi, 17(2) (2016), 249-269.

12 Fanon, The Wretched of the Earth, 31.

13 Louis Althusser, Lenin and Philosophy and Other Essays, translated by Ben Brewster (New York: Monthly Review Press, 1971). 
Western culture he pulls out his knife. ${ }^{14}$ Accomplicing, authorising conquest, theft, brute force - as Said reminds us - western values themselves constrain, immobilise the native, induce paralysis of the jaw, the mouth, an organ of speech. Tempting as it may be to imagine slicing eurocentrism concept by concept, it bears emphasis that, dumbstruck by western values, the west as value itself, Fanon writes a book, doesn't wright a knife.

Injured, outraged by Britain, repositioning the colonial, the US Declaration of Independence, the writing of a 'continental congress' - a congress that, abiding by its name, fucked up a continent - representatives of thirteen colonies claiming the vast territory between two oceans, naturalises settler as native as it transforms colony, dependent entity, to state, independent. It opens by closing, breaking from Britain, asserting the imperative 'for one people to dissolve the political bands which have connected them with another, and to assume...the separate and equal station to which the Laws of Nature and of Nature's God entitle them.' ${ }^{15}$

The formulation recalls, recites Locke, and Hobbes, the intersection of emergence of modernity, the humanities in its first iteration which, while proclaiming universal masculine equality, différantiates human into two mutable conditions, (state of) nature and (civil) society, the former instantiated by the lazy native, the savage American, the latter the civilised, industrious English. The subject is always already otherwise, though not necessarily wise to the other.

As it constitutes a discrete political entity, the text concedes the partiality of such dissolution. Shuttling between undoing and redoing, it fails to push Britain out of the picture. These 'good people' occupying a continent, and not, these uncontinental continentals maybe distinct from those across the Atlantic, but the two remain one. Natural, non-political bands, binds stay solid, indissoluble by declaration. 'Our Brittish brethren... [maybe] deaf to the voice of consanguinity' - more than kin, less than kind - but, even if they never mend, lend the US their ears, learn to empathise, respond to the call of the brother, the two remain one, fraternal, bound by blood, a common father, a lasting relation. The US self redoubles, is always already marked by its British (br)other. Named after a European, the US cannot escape that continent. Without Europe, no United States.

The Declaration's pivotal formulation 'holds these truths...self-evident, that all men are created equal... [and] endowed by their Creator with certain inalienable rights...life, liberty and the pursuit of happiness. This engenders the subject, man, as the self-evident artifice, mimicry of god, masculine rights natural and theologi$\mathrm{cal}$, natural because theological, a divine endowment, thus beyond alienation, forced removal, demonstration or discussion. The Declaration opens by closing debate. 
As it pronounces the equality of all men, the text renounces, stages some as more injured by the tyrannical George III - a monarch, exceptional subjectivity transcending necessity for family name - than others. The 'long train of abuses and usurpations' it lists, as facts - again closing debate - to a 'candid world' - candid signifies impartial, pure, white - accuses Hanover of hurting the good people of America by, among other things, 'imposing taxes without consent... [and] depriving us... of the benefit of trial by jury'. Excise sanctions excision. But such actions could only injure an elite: those qualified to pay taxes, serve on juries. We may receive The Declaration as asserting universal human equality, the US as founded, uniquely amongst nations, upon an idea/l, rather than a social group; the rights bearing subject, the centre emerges in the text as European, Christian, upper class and male. Capitalism and patriarchy inflect the subject who, the text affirms, will resist the British with 'manly firmness', a formulation that equates masculinity with constancy, integrity, settledness.

Making cause consequence, the list of 'injuries and usurpations' - the US, as Wendy Brown does not suggest, ${ }^{16}$ maybe the archetypical state of injury - usurps in turn, accuses George III of incontinent decimation, of having 'plundered our seas, ravaged our Coasts, burnt our towns, and destroyed the lives of our people'. Such acts, 'scarcely paralleled in the most barbarous ages and totally unworthy the Head of a civilized nation', situate Hanover on a world historical scale. His deeds degrade him, not individually but metonymically, from civilisation to a lower, prior condition, barbarousness. The passing of colony as state compels the naturalisation of occupation, achieved by the possessive pronoun: by performatively, insistently declaring Native American land ours, The Declaration transforms settler, usurper to native, possessor and pushes aside the Native. The ultimate injury (dis)locates the Native American spatially, temporally, exiles the group as inhabitants of our frontiers, the merciless Indian Savages, whose known rule of warfare is an undistinguished destruction of all ages, sexes and conditions'.

Hobbes/Locke nominate the Native as American, of the continent; The Declaration denaturalises them, as foreign, Indian, dispossesses, repossesses their territory making the signers repo men - apartheids them to 'our' frontier, the border not of two political entities but unequal conditions, savagery and civilisation. Metaleptically producing its subject as object, victim - abused, threatened by both Britain and, incredulously, the Native American - the text promises the Native a specific fate. Like our terrorist - an analogy, Jodi Byrd points out, ${ }^{17}$ recited by John Yoo $^{18}$ in the torture memos for another imperious George, Bush, who also burnt towns and destroyed lives, mostly in Asia - of a lower condition than Hanover, the savage transgresses the rules of war, indiscriminately slaughters the elderly, children, women. Unmans himself by murdering the infirm. A practitioner, weapon of mass destruction, other to the civilised, Christian, rule-governed, good American man, uncivilisable, the

\footnotetext{
16 Wendy Brown, States of Injury: Power and Freedom in Late Modernity (Princeton, NJ: Princeton University Press, 1995).

17 Jodi A. Byrd, The Transit of Empire: Indigenous Critiques of Colonialism (Minneapolis, MN: University of Minnesota Press, 2011).

18 John C. Yoo, 'Memorandum for William J Haynes II, General Counsel for the Department of Defence, March 142003.
} 
savage loses title to the rights of man, paramountly life. The figure of the savage poses, forces the question of liberty itself.

We may receive The Declaration as grounded upon a claim to universal human equality. But these goods are bads, pharmakonic. The text divulges the relation between civilisation and genocide, human rights and wrongs. It is a declaration of war, a death sentence - authorised by nature and nature's God - to the Native. The Declaration offers its good US people the right to life, liberty - and the pursuit of the Native American.

In its first iteration, the humanities, the disciplines that format the human, charge it by différantiating: as subject, civilised English man in society and, amongst others, savage American in nature. The Native American returns in the second iteration, in relativist anthropology, now side-graded to primitive. Before exiting the disciplinary stage, unsettling incisions between the first and second iterations, the figure of the savage abets the emergence of two extimately accompliced disciplines cortical to the transformation of the human: Anglo-US anthropology, at the intersection of Tylor, and English literature, at Shelley/Macaulay. Tylor concatenates a pair of concepts superfluous at Hobbes/Locke, peculiar to the second iteration: race, understood in the plural, as a graded possession, immutable, and culture, in the singular, as a graded condition, mutable, in the most dispossessed level of which, nature, he locates the savage, racialised as black, geographised as African, though his Anthropology opens by imagining an encounter with an African sailor in the London docks. (Even in his imagination, Tylor resists setting foot in, contamination by Africa. Race apartheids. White resists empathy with black, civilised with savage.)

Shelley's Defense of Poetry theorises literature as the work of imagination, a passive faculty in Hobbes, active, creative in Shelley - concepts mutate, have an itinerary - enabling empathy, an attribute exclusive to the modern, social subject. Reworking Hobbes/Locke, Shelleyan empathy/imagination, not reason, excites improvement, the institution of civil society. Lacking in, dispossessed from its difference, the savage, who cannot author, only imitate, sentencing it to life without literature - a consummation devoutly to be wished - in a state of nature. Indeed, Shelley - while analogising child and savage - nevertheless distinguishes the figure from both child and man, sentencing it concurrently to life in an indeterminate condition outside minority and majority. Such logic, as Spivak reminds us, ${ }^{19}$ makes the savage childless.

These texts deconstitute themselves, raise, again, the question of knowledge. If the emergence of the modern episteme hinges on the other, the savage - an instantiation of epistemic violence - what does that divulge about its centre, the subject, man, which turns upon the savage? What does that divulge of the disciplines that charge man, the humanities, and of the reticulated web of concepts encrusted to man: not 
just reason, society, civilisation - quite apart from the indubitably eurocentric barbarian, primitive - but seemingly innocuous ones like author, imagination, empathy, not to mention right and liberty, that also différantiate? Could we, with Chakrabarty, hold these indispensable? Could postcoloniality cleave them from man, make man leave them?

Macaulay's 'Minute on Indian Education' ${ }^{20}$ (dis)regards the savage as uncivilisable, targets the third term in that hierarchy, the barbarian, a higher state of development, another Indian. Postcoloniality is nauseatingly familiar with the sentence, which mobilises, excites English literature, understood as in Shelley as 'works of imagination', to 'form a class... of persons Indian in blood and color...English in taste...opinions...morals and...intellect'. Literature enables this Indian to imagine himself English without exiting India, upgrade himself to civilisation though remaining, in our terms, racially different. The intersection Shelley/Macaulay/Tylor constitutes the subject with two intertwined levels, immutable and mutable: race forms, culture transforms. Hobbes/Locke only requires the mutable.

Since, as Gauri Viswanathan demonstrates, ${ }^{21}$ English was initially taught, as literature, not in Britain but colonial India, in the wake of the Minute, postcoloniality charges English literature, a classification of writing solicited by the humanities only in its second iteration - Shakespeare could not have known he wrote literature - as emerging to interpellate the barbarian Indian to the superiority of English civilisation. This lingers even at our intersection in which, (re)inscribing Shelley, English literature offers itself as agent of moral improvement. Refusing mendicancy, postcoloniality, rather than make other subject, beseech inclusion in the canon, besieges: calls the discipline itself to question.

As culture uncouples from race, mutates from singular to plural, universalist to relativist, condition - which allows improvement - to possession - which does not - at the intersection of Alice Fletcher/Franz Boas, it (re)turns to the Native American, named Indian, pushed to the US frontier. The Native American must be primitivised, denaturalised yet placed in nature for the formation of the relativist take of culture. Anthropology congratulates itself for democratising the hierarchical, eurocentric, Tylorian notion to the relativist, culture as a discrete whole. But, like race which, as Kamala Visweswaran points out, ${ }^{22}$ it displaces, banishes from the episteme, it others, makes separate and unequal. From Fletcher/Boas to the rest of the disciplinary canon: Bronislaw Malinowski, Clifford Geertz, James Clifford, Saba Mahmood. Rather than describing self-evident difference, relativism, an instantiation of différance, comes before, orders its recognition, capture, settling. A projection in the Freudian sense,

20 See http://www.columbia.edu/itc/mealac/pritchett/00generallinks/macaulay/txt_minute_education_1835. html (accessed 25 September 2017).

21 Gauri Viswanathan, Masks of Conquest: Literary Study and British Rule in India (New York: Columbia University Press, 1989).

22 Kamala Visweswaran, Un/common Cultures: Racism and the Rearticulation of Cultural Difference (Durham, NC: Duke University Press, 2010). 
culture in the plural works its cunning by passing the desire of the subject as that of the other. The empathy the subject stages for the other, conceptualised as participant observation, divulges the ventriloquism - or narcissism, finding oneself in the other, as Truscott powerfully argues - of empathy itself. Cultural relativism speaks for, replaces the other that it fabricates in order to constitute the subject; seduces identity politics to taking, faking itself as opposed to, outside the modern episteme while remaining inside.

Chatterjee argues analogously in Nationalist Thought which, in a searing critique of anthropology, effectively deconstructs relativism as both incoherent - how could one delineate the inside of a culture from its outside - and effect of Orientalist power. He finds west and its outside categories of such power, of the 'thematic' of Orientalism. Indeed, he confronts disciplinary reason, holding that, to modernity, 'The sciences of nature become the paradigm for all rational knowledge... Thus the sciences of society become the knowledge of the Self and...Other. ${ }^{23}$ Bluntly put, Chatterjee damns social science as an effect of power, not knowledge, finds the différance west/outside oxymoronic since the west produces its outside. Or should one say found. For he has recently disavowed this position, and the entirety of subaltern studies, not with a theoretical critique but as a youthful indiscretion, adulthood - the displacement of the father, Ranajit Guha - coinciding with Chatterjee's profession of a discipline, anthropology, Nationalist Thought makes impossible not just to postcoloniality but the ethical subject.

The disciplines stage themselves as offering disinterested knowledge. Its texts divulge their complicity with ideology, the transformation of subjectivity. In its first iteration, which takes science and philosophy as homonymous, works within a national/colonial frame, the humanities produce subjectivity as condition, being, mutable. The second, the disciplines distinguished as we have inherited them, within a global frame, as possession, having, immutable. Both format the subject as modern, in opposition to an uncivilised, naturalised other. The second circumvallates subject and other, subject from other, incarcerates difference. As postcoloniality serves its charge, excites the critique of eurocentrism, its brief confronts the modern episteme, an ordering of concepts in the Derridean sense, including those regulating the quotidian - GMT, the names of continents. And I am not finished with nomination.

Sabelo Ndlovu-Gatsheni holds it possible to exit Europe, shift 'the geography and biography of knowledge. ${ }^{24}$ An avowed decolonialist, he writes in English; critiques race as a concept of coloniality, yet cathects black, a candid coinage, as discrete, unfissured subjectivity. Calls for the de-westernization... and de-Europeanization of knowledge, ${ }^{25}$ yet uncritically affirms Africa in terms that echo Tylor's: it erases Arabs, 
whites, Asians, Berbers from the continent. (Like Tylor and Verwoerd, NdlovuGatsheni writes from fear, the fear of contamination.) He falls back upon the humanities, desires the 're-telling of history' ${ }^{26}$ from the other's perspective. This position iterates Chakrabarty who - reinforcing historicism, culturalism, identity politics supplicates separate and equal, the reworking of other as subject; that the discipline admit, on his own terms, the 'peasant-but-modern...not bereft of the agency of gods, spirits...supernatural beings. ${ }^{27}$ Including, presumably, the Hindu nationalist claim advanced by Narendra Modi that Ganesh proves the existence of plastic surgery in ancient India. But then, Christianity portrays Jesus as walking on water, healing lepers, curing the blind, resurrecting the dead, turning water into wine - a process, alas, his disciples failed to YouTube.

Rather than narrate one against the other, postcoloniality puts history itself to question. Decoloniality celebrates the subject. Necessarily anti-disciplinary, postcoloniality unsettles the structure, episteme that centres man.

If postcoloniality targets eurocentrism - not colonialism, imperialism or empire - it appears a misnomer, pseudonym, under a cape. In misnaming itself, postcoloniality fissures itself. Doubly so, for in (mis)naming itself it divulges its lack of identity with itself, its imperative as overdetermined by another: without eurocentrism postcoloniality would have no charge. Summoned, excited - come get me, put me out of my misery - by that which it opposes, that which it undertakes to finish, postcoloniality, the other heading that critiques the logic of the heading, faces its aporia: we must leave Europe; we can't leave Europe.

Even if, as recent developments suggest, Europe might leave itself.

And I am still not finished with names, though names furnish me.

Take my own, not quite my own, Mohamed Qadri Ismail. At first glance an impeccably Sri Lankan Muslim male moniker: that of the prophet, an honorific, heads my 'given' name, Qadri, tailed by the sur-, family, some male ancestor's name. Since nobody calls me Mohamed, this grants me two first names. To complicate matters further, after we were taught the rule, in grade two at St Thomas' College in Sri Lanka, that every word with a $\mathrm{q}$ is followed by a $\mathrm{u}$, my classmates insisted Qadri - though not an English word - was misspelled, infiltrated the letter. Dumbstruck by eurocentrism, I let myself be called Quadri at school and Qadri everywhere else, a boy with three first names.

26 Ibid., 15.

27 Dipesh Chakrabarty, Provincializing Europe: Postcolonial Thought and Historical Difference (Princeton, NJ: Princeton University Press, 2000), 33. 
But eurocentrism impresses my name, and that of others in this room, more commandingly, less conspicuously. Sri Lankan Muslims did not take family names before British colonialism, such structure of nomination being a colonial, patriarchal imposition, interpellation. My great-grandparents survived without surname. When eurocentrism inflects something as personal, intimate as one's name, when one reinforces eurocentrism in doing something as banal, quotidian as saying, spelling or signing one's name, one confronts the impossibility of leaving Europe. Eurocentrism lasts, cements my name.

I could traverse the third world: baila in Colombo, bar-hop in Barbados and, of course, braai in Cape Town. I could go here, there, everywhere. I would never leave Europe. 